\title{
POLA PERKEMBANGAN MORFOLOGI FISIK KOTA DI CEKUNGAN BANDUNG PERIODE 2009 - 2018
}

\author{
DEVELOPMENT PATTERN OF URBAN MORPHOLOGY IN \\ BANDUNG BASIN PERIOD 2009-2018
}

\author{
${ }^{7}$ Ramadhan Pascawijaya, ${ }^{2}$ Bowo Susilo, dan Prima Widayani ${ }^{3}$ \\ Program Magister Penginderaan Jauh, Fakultas Geografi \\ Universitas Gadjah Mada
}

Submitted: 15-04-2019; Revised: 07-09-2019; Accepted: 07-09-2019

\begin{abstract}
Land development will be occur from time to time, the developments phenomenon will have either positive or negative impact. The impact of this phenomenon will affect various aspects, such as socioeconomic, mobility, land quality, and more. So the study on land development is required to evaluate and anticipate the negative impact on some region. To do evaluating and anticipating unwanted impacts a study can be carried out to become the basis for regional development or regional planning. one of them is to examine the pattern of urban development that will be used as a reference for regional development planning that will occur in the future. This study aims to analyze the development of urban physical morphology in Bandung Basin period $2009-2018$. The method in this research is quantitative descriptive in the form of data collecting, data processing, modelling, and mapping. The research method is quantitative and qualitative in the form of data collection, data processing, modeling and mapping. The method of applying quadrant and burgess models to find the value of built-up land density that can reflect information on the phenomenon of built-up area development seen from the built-up area density in each agreed zone with geometric and quadrant models. The results in this research shows that the morphological structure of developed land in Bandung Basin is concentric with the highest density of $0.3459 \mathrm{~km}^{2}$ which is centered in Cimahi and Bandung, also development is elongated and along the road with the majority of the land development create a leapfrog pattern, so it can be concluded that urban morphology in Bandung Basin is concentric with the linear development which is leapfrog.
\end{abstract}

Keywords: Urban Morphology; Developed Land; Pattern; Development; Remote Sensing.

\begin{abstract}
ABSTRAK
Perkembangan lahan terbangun akan terjadi seiring dengan waktu, fenomena perkembangan lahan terbangun akan membawa dampak yang bersifat baik ataupun buruk. Dampak fenomena yang ditimbulkan akan mempengaruhi berbagai aspek, di antaranya: sosial ekonomi masyarakat, mobilitas, kualitas lahan, dan lainnya. Sehingga kajian mengenai perkembangan lahan terbangun diperlukan untuk mengevaluasi serta mengantisipasi dampak buruk yang ditimbulkan disuatu wilayah. melakukan evaluasi dan mengantisipasi dampak yang tidak diinginkan dapat dilakukan kajian untuk jadi dasar dalam pengembangan wilayah ataupun perencanaan wilayah. salah satunya
\end{abstract}

${ }^{*}$ Corresponding author: Rama.pascawijaya@gmail.com

Copyright $\odot 2020$ THE AUTHOR(S).This article is distributed under a Creative Commons Attribution-Share Alike 4.0 International license. Jurnal Teknosains is published by the Graduate School of Universitas Gadjah Mada. 
adalah dengan mengkaji pola perkembangan yang telah terjadi untuk dijadikan rujukan perencanaan pengembangan wilayah yang akan terjadi dimasa yang akan datang. Penelitian ini bertujuan untuk menganalisis perkembangan morfologi fisik kota di Cekungan Bandung pada periode 2009 - 2018. Metode penelitian ini bersifat kuantitatif dan kualitatif berupa pengumpulan data, pengolahan data, pemodelan dan pemetaan. Metode menerapkan model kuadran dan burgess untuk mencari nilai kepadatan lahan terbangun yang dapat mencerminkan informasi fenomena perkembangan lahan terbangun yang dilihat dari kepadatan lahan terbangun pada setiap zona yang telah dipisahkan dengan model geometrik dan kuadran. Hasil Penelitian menampilkan Cekungan Bandung mempunyai struktur morfologi fisik lahan terbangun yang bersifat konsentris dengan kepadatan tertinggi $0.3459 \mathrm{Km}^{2}$ yang terpusat pada kota Cimahi dan kota Bandung, serta mempunyai perkembangan yang bersifat memanjang dan mengikuti arah jalan dengan mayoritas perkembangan lahan terbangun membentuk pola meloncat (leapfrog), sehingga dapat disimpulkan bahwa morfologi fisik kota di Cekungan Bandung mempunyai sifat konsentris dengan perkembangan secara linier yang bersifat meloncat.

Kata Kunci:Morfologifisik kota; Lahan Terbangun; Pola Perkembangan; Pengindraan Jauh.

\section{PENGANTAR}

Perkembangan wilayah merupakan fenomena yang tidak dapat dihindari. Adanya aksesibilitas yang baik dan tersedianya lahan yang menguntungkan menjadi faktor berpengaruh terhadap fenomena perkembangan wilayah, (Adeel, 2010). Kota mengalami pertumbuhan yang cepat dibanding desa. Perkembangan kota adalah perluasan sedangkan pertumbuhan kota merupakan perluasan wilayah kota sehubungan dengan peningkatan jumlah dan ukuran pemukiman, (Brueckner dan Helsley, 2011; Jat, dkk, 2017). Kota mengalami perluasan yang diakibatkan oleh faktor pembangunan transportasi, faktor kependudukan, dan faktor fisik (topografi dan geologi) kota tersebut yang tergantung pada tersedianya sejumlah faktor seperti aksesibilitas, (Mundia dan Aniya, 2017).
Kota mengalami perubahan dari waktu ke waktu. Perubahan tersebut membentuk suatu pola yang dinamakan morfologi kota, (Whitehand, 1987 dalam Sanders. dan Beker, 2016). Morfologi kota yaitu struktur dan pola kota yang digunakan untuk menggeneralisasi peta, (Li dan Ai, 2004). Sementara itu menurut, Srinurak, dkk., (2016) menyatakan bahwa morfologi perkotaan mempelajari bagaimana kota berkembang dan bertransformasi.

Morfologi fisik yang dimaksud dalam penelitian ini dikhususkan dalam pengkajian lahan terbangun. (BSN - Badan Standar Nasional 2010), menyatakan bahwa lahan terbangun merupakan objek permukaan bumi yang telah mengalami substitusi penutup lahan secara alami atau semi alami dengan penutup lahan buatan yang bersifat artifisial serta bersifat kedap air. Pengertian tersebut dapat digambarkan seperti: rumah toko (ruko), permukiman, kantor, dan bangunan yang mempunyai struktur fisik serta tampak jelas.

Lahan terbangun akibat perluasan perkembangan kota mengakibatkan dampak serius pada lingkungan dan perkembangan sosial ekonomi, (Yuan dkk., 2005; Zhang dan $\mathrm{Xu}, 2015)$. Pengkajian perkembangan lahan terbangun merupakan wujud kepedulian terhadap pembangunan berkelanjutan dan pengelolaan sumber daya alam, (Worku, dkk, 2016). Pengkajian dapat dilakukan dengan berbagai model salah satunya adalah dengan pemodelan spatiotemporal. (Yingui, dkk., 2011) dan (Zanganeh, dkk., 2011) mengungkapkan bahwa pemodelan spatiotemporal dapat merefleksikan perubahan penggunaan lahan yang berguna untuk pengambilan keputusan dalam perencanaan lahan di perkotaan. (Militino.A.F. dkk, 2018) mengungkapkan bahwa pemodelan spatiotemporal dapat digunakan dalam menganalisis data pengindraan jauh.

(Hari dan Rizki, 2016) dan (Hartono dan Purwanto 2017), mengungkapkan bahwa pengindraan jauh merupakan teknik paling baik dan paling cepat untuk mendapatkan data penggunaan lahan dan penutup lahan yang dapat dipercaya. Selain itu, (Xiuwan, 2010) dan (Haack dan Rafter, 2006) mengungkapkan 
bahwa pengindraan jauh memudahkan dalam pengambilan keputusan suatu perencanaan wilayah. (Taylor, dkk., 2013) menyatakan bahwa integrasi pengindraan jauh dan GIS memberikan informasi spasial terbaru dan dapat membantu menyelesaikan permasalahan spasial.

Perkembangan lahan terbangun yang terus menerus terjadi yang membawa dampak baik ataupun buruk. dapat diantisipasi dengan melihat perkembangan yang terjadi secara temporal untuk dijadikan sebagai bahan pertimbangan dalam pengembangan wilayah dan pembangunan wilayah. Perkembangan pada suatu wilayah akan mempunyai pola, dan kecenderungan, sehingga pemerintah dapat mengantisipasi kemungkinan yang tidak diinginkan dengan mempertimbangkan pola dan kecenderungan perkembangan yang terjadi pada kawasan tertentu. Pola perkembangan wilayah di setiap wilayah akan berbeda sehingga perencanaan yang dibutuhkan akan berbeda pada tiap wilayah. Oleh karena itu, disetiap daerah harus mengkaji fenomena perkembangan morfologi fisik kota. Pengkajian perkembangan lahan terbangun tidak hanya untuk mengantisipasi namun juga dapat menjadi acuan untuk mengoptimalkan sumber daya manusia yang terintegrasi dengan sumber daya lahan dalam membangun sosial ekonomi masyarakat.

Uraian di atas menyatakan bahwa diharuskan adanya kajian pola perkembangan lahan terbangun yang terjadi untuk mengantisipasi ataupun untuk mengevaluasi perkembangan untuk dijadikan referensi dalam suatu perencanaan dan kawasan prioritas perkembangan serta penyediaan fasilitas dan utilitas yang dapat menunjang aktivitas masyarakat pada suatu wilayah. kajian perkembangan lahan terbangun dapat memanfaatkan teknologi pengindraan jauh yang bersifat temporal, sehingga teknologi pengindraan jauh dapat meminimalisir waktu yang digunakan dalam penelitian dan perolehan data terkait penelitian yang dilakukan.

Penginderaan jauh merupakan ilmu yang memperoleh data suatu objek dengan melakukan analisis data tanpa adanya kontak langsung untuk memperoleh informasi yang diinginkan (Lillesand, 1997 dalam Danoedoro, 2012). Perkembangan wilayah secara fisik dapat dilakukan pemantauan menggunakan teknologi pengindraan jauh saat ini. Resolusi temporal yang dimiliki teknologi pengindraan jauh dapat dimanfaatkan untuk mengambil Informasi permukaan bumi secara spasial dan komprehensif. Berdasarkan pengertian tersebut pemanfaatan teknologi pengindraan jauh akan lebih mengoptimalkan dana yang dikeluarkan dan mempersingkat waktu pengkajian perkembangan wilayah.

(Sutanto, 1986), mengungkapkan bahwa data citra merupakan alat yang baik sekali untuk (monitoring) perubahan lahan yang cepat seperti pembukaan daerah hutan, pemekaran kota, perubahan kualitas lingkungan dan perluasan lahan garapan. Teknologi penginderaan jauh dengan resolusi temporal dapat dimanfaatkan sebagai data dasar yang dibutuhkan untuk mengkaji fenomena keruangan yang ada pada wilayah perkotaan dengan waktu yang lebih efisien, Sehingga pengkajian morfologi fisik kota dapat dilakukan dengan waktu yang singkat menggunakan data penginderaan jauh secara temporal dan dapat memberikan informasi yang dapat dijadikan sebagai rujukan untuk mengantisipasi dampak yang tidak diinginkan pada wilayah - wilayah yang mengalami perkembangan, khususnya pada pengambilan keputusan untuk wilayah prioritas dalam pengembangan lahan terbangun.

Penelitianini bertujuanuntuk menganalisis perkembangan morfologi fisik kota di Wilayah Cekungan Bandung pada periode 2009 - 2018 menggunakan data pengindraan jauh. Data pengindraan jauh dimanfaatkan sebagai acuan dalam menganalisis ketampakan permukaan bumi pada wilayah penelitian. Hasil penelitian dapat dimanfaatkan sebagai data untuk melakukan pemodelan spasial, ataupun sebagai pertimbangan dalam melakukan perencanaan wilayah, untuk menunjang fungsi wilayah secara optimal. 


\section{Metode}

Metode yang dipakai pada penelitian ini dengan cara melihat ketampakan lahan terbangun dari citra pengindraan jauh dan melakukan analisis secara matematis dengan menerapkan model Geometrik/kuadran untuk menganalisis ketampakan struktur morfologi fisik kota serta pola perkembangan lahan terbangun di wilayah penelitian pada periode 2009 - 2018.

Pada penelitian ini menggunakan data pengindraan jauh bersifat primer serta temporal. (Alqurashi dan Kumar 2013) menyatakan bahwa resolusi temporal dan
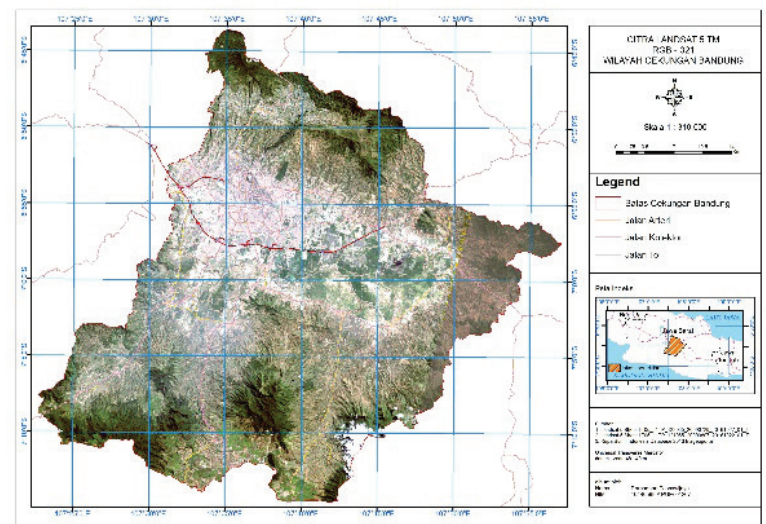

spasial memungkinkan bagi pengindraan jauh untuk mendeteksi perubahan ataupun perkembangan suatu objek di permukaan bumi dalam skala yang luas dan membantu dalam mendapatkan informasi seperti: pergeseran pola pertanian, tingkat stres tanaman, pemantauan kebencanaan, penggunaan lahan dan perubahan tutupan lahan. Data pengindraan jauh yang dipakai adalah Citra Landsat 5 TM dan Citra Landsat 2018 OLITIRS dengan resolusi $30 \times 30 \mathrm{~m}$. Citra Landsat merupakan data pengindraan jauh yang dijadikan sebagai data utama pada penelitian ini. Landsat dapat dilihat dalam gambar 1

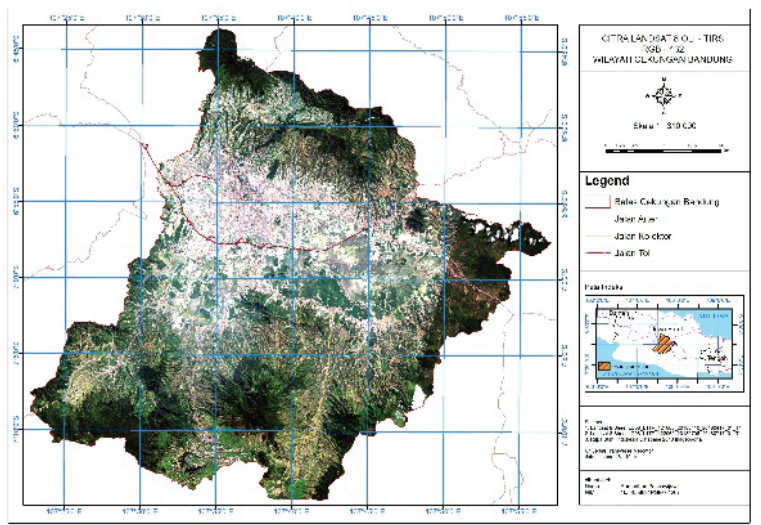

Gambar 1.

Citra landsat tahun 2009 (a) dan Citra landsat tahun 2018 (b)

Sumber: Dokumentasi Penelitian tahun 2018

Pemilihan citra landsat yang merupakan citra dengan klasifikasi resolusi menengah dapat digunakan untuk melakukan ekstraksi data tutupan lahan pada objek permukaan bumi. (Horvat, 2017), menyatakan bahwa Landsat dapat digunakan untuk ekstraksi data tutupan lahan/penggunaan lahan dengan metode visual ataupun digital yang mengombinasikan pada pengolahan data citra dengan pengetahuan peneliti mengenai wilayah yang akan diekstrak serta kombinasi band yang tersedia pada citra landsat. Data diperlukan empat sheet citra Landsat, sehingga harus dilakukan koreksi untuk menyelaraskan informasi pixel dari keempat data citra yang digunakan. Dilakukan koreksi geometrik sampai pada tingkat At Surface Reflectance dengan menggunakan Software Envi dengan tools "Band Math", dan dilakukan perhitungan secara matematis terhadap setiap band yang diperlukan dalam interpretasi citra. Berikut persamaan untuk mencari nilai At Surface Reflectance tanpa sudut matahari.

$$
\rho \lambda^{\prime}=\text { M } \rho . Q c a l+A \rho
$$

Keterangan :

$\rho \lambda>\quad$ : Hasil perhitungan nilai pixel

Qcal : Nilai Pixel (DN)

$\mathrm{M \rho}$ : konstanta rescalling (REFLECTANCE_MULT_BAND)

A $\rho$ : konstanta penambah (REFLECTANCE_ADD_BAND)

$\theta_{\mathrm{SE}} \quad$ : Sudut Matahari

Sumber: (USGS, 2019)

Untuk mendapatkan nilai At Surface Reflectance diperlukan nilai sudut matahari dengan melihat informasi yang tersedia 
pada METADATA, dan dapat dilakukan perhitungan dengan rumus berikut:

$\theta_{\mathrm{SE}}=$ nilai Pixel / Sin

Sumber: (USGS, 2019)

Perhitungan At Surface Reflectance dengan melibatkan sudut matahari dapat menggunakan informasi dari METADATA berikut persamaannya:

$$
\rho \lambda^{\prime}=(\mathrm{M} \rho . \mathrm{Qcal}+(\mathrm{A} \rho)) / \theta_{\mathrm{SE}}
$$

Sumber: (USGS, 2019)

Nilai pixel yang telah terkonversi memiliki satuan $\left(\mathrm{W} / \mathrm{m}^{2}\right.$.sr. $\left.\mu \mathrm{m}\right)$, koreksi radio metrik dilakukan untuk mengubah nilai pixel mempunyai kemiripan pada lembar satu dengan lainnya. Nilai yang telah terkonversi tidak dapat ditampilkan ataupun dibandingkan secara visual, tetapi dapat dibandingkan dengan nilai pixel pada citra yang belum dilakukan koreksi radio metrik.

Kedua citra yang telah diekstraksi data dilakukan validasi untuk melihat tingkat ketelitian data dengan cara mencocokkan citra interpretasi dengan peta yang dianggap benar, ataupun melihat keadaan aktual dengan mengukur sesuai dengan resolusi citra, serta mencocokkan peta interpretasi dengan citra resolusi tinggi Google earth. Pencocokan dilakukan dengan mengambil sampel di wilayah penelitian dengan dua kategori yaitu terbangun dan non terbangun dengan jumlah yang telah ditentukan dengan menerapkan perhitungan matematis yang mengukur dari jumlah pixel yang terdapat pada wilayah penelitian. Sampel dalam penelitian ini menggunakan perhitungan yang dikemukakan oleh Slovin sebagai berikut:

$$
n=\frac{N}{1+N e^{2}} \ldots \ldots \ldots(n)
$$

Keterangan:

$\mathrm{n}=$ Jumlah piksel sampel

$\mathrm{N}=$ Jumlah Populasi

$\mathrm{e}=$ TarafSignifikansi (Toleransi Kesalahan)

(Ansar. dkk, 2017)
Berikut perhitungan pada sampel penelitian ini dengan taraf signifikansi 95\% yaitu 0,05 .

$$
\begin{aligned}
& n=\frac{21.343 .080}{1+21.343 .080 \times(0,05 \times 0,05)} \\
& =399,9925 \\
& =400 \text { sampel }
\end{aligned}
$$

Berdasarkan perhitungan yang telah dilakukan, sampel yang harus diambil sebanyak 400 sampel untuk menghitung tingkat akurasi dari penelitian mengenai simulasi spasial perkembangan morfologi fisik kota. Sampel yang telah ditentukan jumlahnya dan didistribusikan secara acak tanpa memperhitungkan bobot pada klasifikasi lahan terbangun ataupun non terbangun.

Menentukan akurasi dilakukan dengan cara mencocokkan sampel antara peta interpretasi dengan keadaan di lapangan. sehingga menghasilkan jumlah interpretasi yang benar dan jumlah interpretasi yang salah. Kedua nilai tersebut dipersentasekan untuk mengetahui akurasi interpretasi citra pengindraan jauh. Sehingga data dengan nilai akurasi tinggi dapat dijadikan untuk data dasar dalam menganalisis morfologi lahan terbangun pada wilayah penelitian.

Data yang telah diolah dan dinyatakan layak dengan menimbang akurasi dapat dijadikan sebagai dasar dalam penelitian ini dilakukan analisis lebih lanjut untuk mengkaji perkembangan lahan terbangun dengan menerapkan analisis visual untuk melihat struktur perkembangan kota menggunakan metode linkage dengan melihat bentuk keseluruhan lahan terbangun. (Tallo, dkk 2015), mengungkapkan analisa linkage dapat menggunakan tiga pendekatan salah satunya adalah secara visual, analisa secara visual dapat mengambil lima unsur yang terdapat pada kawasan untuk menganalisis pola perkembangan yaitu : garis, koridor, sumbu, sisi, dan irama.

Analisis secara visual akan ditunjang dengan analisis yang didasarkan pada perhitungan matematis dengan cara menerapkan model Burgess untuk membuat 
titik tengah sebagai pembagi zona menjadi empat bagian sub zona berdasarkan arah mata angin. Lahan terbangun yang terbagi menjadi empat zona dilakukan perhitungan matematis antara luas sub zona dengan luas lahan terbangun yang terdapat pada sub zona sehingga akan menghasilkan nilai kepadatan lahan terbangun yang terdapat pada setiap sub zona. Klasifikasi dilakukan dengan melihat nilai kepadatan lahan terbangun dari setiap sub zona di wilayah penelitian. Lebih jelasnya untuk pembagian sub zona dapat dilihat dalam gambar 2

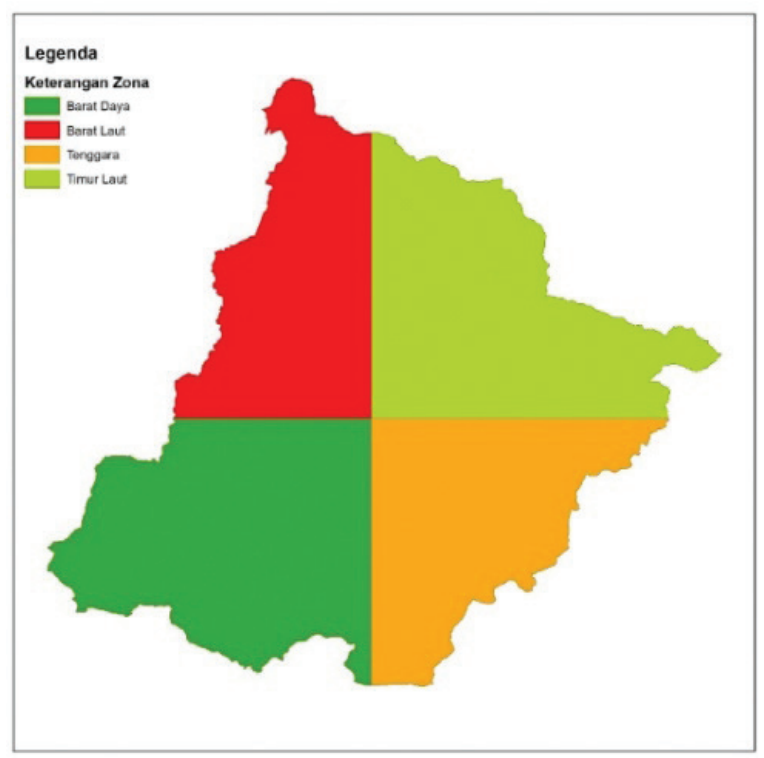

Gambar 2.

Pembagian subwilayah

Sumber: Dokumentasi Penelitian tahun 2018

Wilayah Cekungan Bandung yang telah terbagi menjadi sub zona berdasarkan arah mata angin menjadi dasar untuk membagi luasan lahan terbangun. Analisis struktur kota dapat dilakukan dengan menghitung kepadatan lahan terbangun pada setiap zona dengan rumus matematika dasar untuk mencari luas persegi yaitu: sisi x sisi, luas yang dihasilkan dikalikan kembali dengan resolusi spasial citra Lansat yang digunakan yaitu: $900 \mathrm{~m}^{2}$. informasi luas digunakan untuk menghitung kepadatan lahan terbangun yang ada pada setiap sub wilayah.
Kepadatan yang dihasilkan mempunyai nilai yang berbeda pada setiap sub wilayah dan mencerminkan struktur morfologi fisik kota yang ada di Cekungan Bandung. Nilai yang berbeda diperlukan pengkelasan dengan menggunakan kode yang didasarkan pada interval nilai kepadatan pada setiap sub zona wilayah yang telah terbagi menjadi empat bagian.

Kajian mengenai morfologi fisik kota pada penelitian ini tidak hanya bertujuan untuk menganalisis struktur namun juga melakukan analisis terhadap perkembangan yang terjadi pada tahun 2009 - 2018, dengan melakukan perhitungan secara matematis dengan menggabungkan model Burgess serta didasarkan pada jarak terhadap titik pusat wilayah penelitian.

Titik pusat wilayah akan dibagi menjadi beberapa bagian pada model burgess yang memisahkan dia wilayah yaitu wilayah inti (kota) dan wilayah luar (pinggiran kota). Sedangkan pada penelitian ini diselaraskan dengan titik pusat sebagai titik tengah dari wilayah Cekungan Bandung yang dibagi dengan interval jarak dari titik tengah hingga luar sub wilayah terjauh di Cekungan Bandung dengan interval $2 \mathrm{Km}$. Pengambilan interval radius dilakukan dengan asumsi keterjauhan jangkauan dari suatu daerah terhadap titik pusat. Sehingga radius $2 \mathrm{Km}$ mempunyai jangkauan yang tidak terlalu jauh ataupun tidak terlalu dekat dan bisa dikatakan cukup. Sehingga terdapat beberapa sub wilayah berdasarkan radius yang mempunyai informasi perkembangan dan kepada lahan terbangun di Cekungan Bandung.

Pada setiap submikro wilayah akan mempunyai kepadatan lahan terbangun. Sehingga kepadatan dapat dijadikan sebagai dasar dari melakukan klasifikasi pola perkembangan yang terdapat pada wilayah cekungan bangun yang dihitung dari setiap sudut submikro wilayah dengan memberikan interval pada setiap kepadatan lahan terbangun. Dapat dilihat pembagian sub wilayah mikro dalam gambar 3 


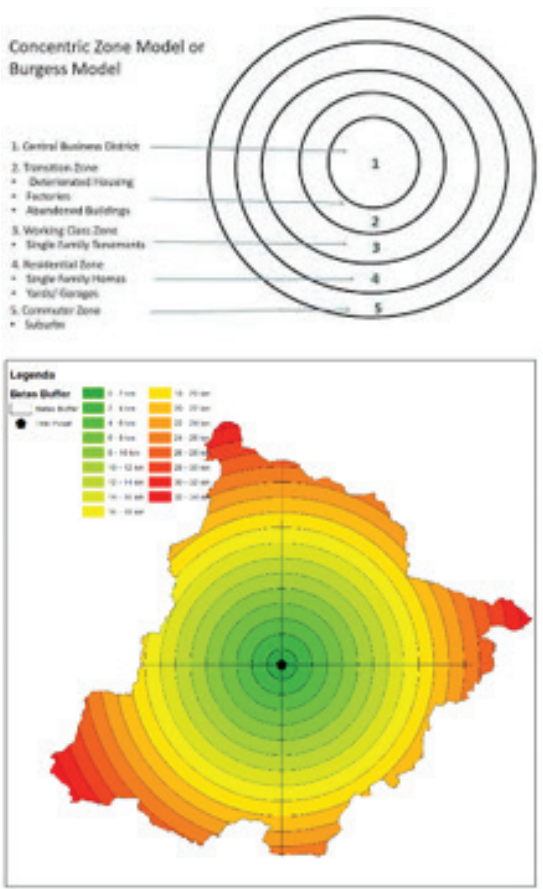

Gambar 3.

Model Burgess (a) dan Pembagian sub wilayah mikro (b)

Sumber: Yunus, 1994

Metode untuk melakukan analisis sifat perkembangannya dapat dilakukan secara visual yaitu dengan metode linkage. Pada metode linkage akan melihat setiap sudut dari perkembangan lahan terbangun yang terjadi pada periode 2009 - 2018. Analisis linkage secara visual akan menghasilkan klasifikasi dengan menimbang kelima unsur yang ada pada wilayah pinggiran kota yang terjadi perkembangan sehingga dapat diselaraskan antara ketampakan morfologi fisik kota pada setiap tahun dengan klasifikasi pola perkembangan kota. Klasifikasi perkembangan kota radial lahan terbangun akan bersifat merata pada setiap arah untuk perubahan lahan non-terbangun menjadi lahan terbangun, klasifikasi linier (memanjang) akan teridentifikasi dengan perkembangan lahan terbangun yang merujuk pada sekitar jalan raya, sedangkan perkembangan kota dengan tipe leapfrog (meloncat) akan terlihat tidak merata pada setiap perkembangan yang terjadi dan cenderung tidak mempunyai wilayah penghubung serta fenomena perkembangan yang terjadi tidak dipicu oleh lahan terbangun sebagai penghubung untuk berkembang. Sifat perkembangan aktual yang terjadi tidak menutup kemungkinan untuk memiliki dua sifat dalam satu kawasan, dan sangat bergantung pada luasan daerah penelitian.

Kecenderungan perkembangan lahan terbangun dapat terlihat dengan data yang telah diekstrak menjadi format raster yang terbagi menjadi 3 klasifikasi yaitu; lahan terbangun tahun 2009, perkembangan lahan 2009-2018, dan lahan terbangun 2018. Data perkembangan yang diperoleh dianalisa menggunakan tools "trend" dalam Land Change Modeler pada software IDRISI SELVA ataupun dapat dilakukan secara visual untuk melihat kecenderungan arah perkembangannya.

\section{HASIL DAN PEMBAHASAN}

Pengkajian penelitian ini menghasilkan nilai yang merujuk pada pola perkembangan lahan terbangun di Cekungan Bandung. Secara visual dengan melihat penampakan perkembangan lahan terbangun yang terjadi mempunyai perkembangan yang struktur tipe gurita, sedangkan secara spasial statistik, nilai yang dihasilkan mencerminkan pola perkembangan terkategori pada kelas (leapfrog), dan bersifat linier dan merujuk pada arah pusat kota. Adapun penelitian yang telah dilakukan oleh Zhang dan Xu, (2015) dilakukan di Beijing, China. Mempunyai pola perkembangan yang mengelompok dan cenderung berorientasi pada pusat kota. berdasarkan hasil penelitian yang telah disebutkan terdapat kesimpulan yaitu setiap perkembangan akan merujuk pada pusat kota/ pusat aktivitas masyarakat dengan menimbang berbagai faktor. Penelitian yang dilakukan mempunyai perbedaan dalam hasil, metode dan wilayah yang dikaji, hal tersebut dikarenakan faktor yang mempengaruhi perkembangan pada setiap wilayah bersifat kompleks dan berbeda.

Pengumpulan data yang dilakukan dengan metode pengindraan jauh memiliki akurasi yang cukup tinggi. Pada kedua citra sehingga data yang dihasilkan dapat dijadikan sebagai dasar untuk menganalisis morfologi fisik kota. lebih jelasnya dapat dilihat dalam tabel 1. 
Tabel 1.

Akurasi interpretasi Landsat 5 TM dan 8 OLI-TIRS

\begin{tabular}{l|l|l|l|l}
\hline \multicolumn{5}{c}{ Akurasi Interpretasi } \\
\hline Tahun & Benar & Salah & Total & \% Akurasi \\
\hline 2009 & 345 & 55 & 400 & 86.25 \\
\hline 2018 & 375 & 25 & 400 & 93.75 \\
\hline
\end{tabular}

Sumber : Hasil Analisis 2019

Sampel yang telah terdistribusi secara dilakukan pada setiap tahun citra dengan jumlah 400 sampel yang terbagi pada kategori lahan terbangun dan non terbangun untuk menghitung akurasi interpretasi pada setiap citra dan menyimpulkan bahwa data dapat dijadikan sebagai dasar dalam penelitian.

Tabel 1 menunjukkan akurasi pada tahun 2009 sebesar $86,25 \%$ dengan sampel yang benar adalah 345 sedangkan sampel yang salah 55 sampel. Tahun 2018 mempunyai akurasi sebesar $93,75 \%$ dengan sampel yang benar 375 dan kesalahan 25 sampel. Didasarkan pada akurasi yang telah dilakukan perhitungan dapat disimpulkan bahwa data memiliki akurasi yang cukup tinggi dan baik untuk dijadikan sebagai dasar dalam penelitian ini.

Perbedaan akurasi yang dihasilkan dalam interpretasi citra dapat disebabkan oleh berbagai hal, seperti: knowledge, spesifikasi citra, sampel klasifikasi citra, algoritma citra, dan tingkat koreksi citra yang dibutuhkan. Perbedaan spesifikasi terletak pada jumlah band yang terdapat pada jenis citra. Spesifikasi tersebut dapat dilihat dalam tabel 2

Tabel 2.

Spesifikasi Citra Landsat 5 TM dan Landsat8 OLI-TIRS

\begin{tabular}{|c|c|}
\hline Citra & Gelombang \\
\hline \multirow{7}{*}{ 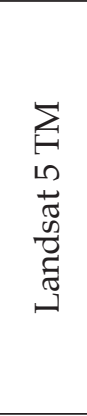 } & Band 1 Biru $(0,45-0,52 \mathrm{~nm})$ \\
\hline & Band 2 Hijau $(0,52-0,60 \mathrm{~nm})$ \\
\hline & Band 3 Merah $(0,63-0,69 \mathrm{~nm})$ \\
\hline & Band 4 Inframerah Dekat $(0,76-0,90 \mathrm{~nm})$ \\
\hline & Band 5 Inframerah dekat $(1,55-1,75 \mathrm{~nm})$ \\
\hline & Band 6 Termal $(10,40$ - 12,50 nm) \\
\hline & $\begin{array}{l}\text { Band } 7 \text { Inframerah tengah }(2,08-2,35 \\
\mathrm{nm})\end{array}$ \\
\hline
\end{tabular}

\begin{tabular}{|c|c|}
\hline Citra & Gelombang \\
\hline \multirow{11}{*}{ 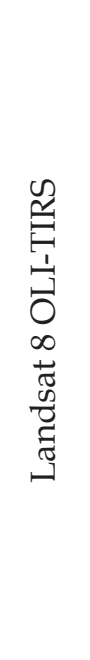 } & Band 1 Biru Awan(0,43 - 0,45 nm) \\
\hline & Band 2 Biru $(0,450-0,51 \mathrm{~nm})$ \\
\hline & Band 3 Hijau (053 - 0,59 nm) \\
\hline & Band $4 \operatorname{Merah}(0,64-0,67 \mathrm{~nm})$ \\
\hline & Band 5 Inframerah dekat $(0,85-0,88 \mathrm{~nm})$ \\
\hline & $\begin{array}{l}\text { Band } 6 \text { Inframerah Jauh } 1(1,57-1,65 \\
\text { nm) }\end{array}$ \\
\hline & $\begin{array}{l}\text { Band } 7 \text { Inframerah Jauh } 2(2,11-2,29 \\
\text { nm) }\end{array}$ \\
\hline & Band 8 Pankromatik $(0,50-0,68 \mathrm{~nm})$ \\
\hline & Band 9 Awan(1,36 - 1,38 nm) \\
\hline & Band 10 Termal $1(10,6-11,19 \mathrm{~nm})$ \\
\hline & Band 11 Termal 2 (11,5 - 12,51 nm) \\
\hline
\end{tabular}

Sumber: (USGS, 2013)

Jumlah band pada landsat 8 tahun 2018 mempunyai jumlah band yang lebih bervariasi dibandingkan dengan landsat 5 . Peningkatan spesifikasi pada band infra merah pada landsat 8 mempunyai tiga tingkatan, sehingga akan mempunyai informasi yang lebih rinci terhadap objek yang mempunyai kepekaan terhadap gelombang inframerah. Variasi band yang digunakan citra landsat akan lebih memudahkan untuk mengekstrak data pengindraan jauh, terutama pada analisis secara digital, kemudahan akan terletak dalam menentukan sampel interpretasi dalam melakukan ekstraksi dengan metode Supervised (klasifikasi terbimbing). Penentuan sampel akan lebih mudah dengan menggabungkan band yang bervariasi dalam kombinasi RGB yang telah disediakan pada software pengolahan data citra pengindraan jauh. Inframerah yang dikembangkan pada landsat 8 OLI-TIRS akan memudahkan karena mempunyai gelombang yang lebih peka terhadap air. Sehingga pengambilan sampel dapat dengan mudah dilakukan untuk membedakan lahan terbangun dengan vegetasi pada wilayah lereng gunung yang mempunyai kawasan lahan terbangun tidak teratur.

Data pengindraan jauh yang telah diekstrak mempunyai informasi yang cukup untuk melakukan analisis struktur morfologi fisik kota. data citra akan mempunyai bentuk 
pixel, sehingga untuk mendapatkan informasi yang dibutuhkan, data diperlukan perhitungan untuk mengetahui luasan lahan terbangun pada tahun yang diperlukan dengan cara menghitung jumlah pixel dikalikan dengan luasan pada satu pixel (resolusi spasial). Informasi luas lahan terbangun akan dibagi menjadi empat sub zona dan menghasilkan kepadatan lahan terbangun untuk mengetahui struktur morfologi kota dengan melakukan perhitungan matematis. Hasil yang dari analisis kepadatan lahan terbangun untuk mengetahui struktur morfologi fisik kota dapat dilihat dalam tabel 3.

Tabel 3.

Kepadatan Struktur Morfologi Fisik Kota

\begin{tabular}{l|l|l|l|l}
\hline KD Wilayah & \multicolumn{1}{|c|}{ Luas Zona } & \multicolumn{1}{|c|}{ Luas Lahan Terbangun } & Kepadatan lahan terbangun & Kode \\
\hline BD & 541.84 & 28.532138 & 0.052657 & 1 \\
\hline BL & 378.26 & 130.85682 & 0.345936 & 4 \\
\hline TL & 502.07 & 75.452746 & 0.150282 & 2 \\
\hline
\end{tabular}

Hasil Analisis 2019

Pada tabel 3. mencerminkan wilayah barat daya (BD) dan tenggara (TGR) memiliki densitas lahan terbangun yang kecil, hal ini dikarenakan pada wilayah BD dan TGR merupakan wilayah pinggiran yang mempunyai fasilitas dan utilitas rendah, serta jangkauan pusat kota yang cukup jauh. Pada wilayah timur laut (TL) mempunyai kepadatan yang cukup tinggi dibandingkan dengan TGR dan BD, hal ini dikarenakan pada wilayah Timur Laut mengalami perkembangan yang diakibatkan oleh adanya industri, dan perguruan tinggi negeri, wilayah TL merupakan bagian dari wilayah Kota Bandung dan Kota Sumedang, sehingga fasilitas dan utilitas yang cukup lengkap dan infrastruktur yang baik pada wilayah TL. Sedangkan pada wilayah Barat Laut (BL) merupakan wilayah yang mempunyai kepadatan yang tinggi. Hal ini dikarenakan fasilitas dan utilitas lengkap, serta infrastruktur yang baik. Secara administratif wilayah BL merupakan Wilayah Kota Cimahi, Kota Bandung, dan Kabupaten Bandung Barat. Dan pada wilayah BL mempunyai pusat ekonomi yaitu (Kota Bandung, dan Kota Cimahi), serta ikon wisata yaitu pada kawasan Bandung Barat. Hal ini akan mempengaruhi bentuk kota secara tidak langsung.

Berdasarkan uraian di atas dapat disimpulkan bahwa pada Cekungan Bandung mempunyai satu sub wilayah dengan tingkat densitas yang tinggi pada sub wilayah BL (Barat
Laut) dengan tingkat kepadatan 0.345936 . Hal tersebut merupakan konsentrasi dari distribusi lahan terbangun yang berada pada Cekungan Bandung, sehingga pada wilayah Cekungan Bandung mempunyai struktur morfologi fisik lahan terbangun yang bersifat konsentris pada tahun 2018. Lebih jelasnya dapat dilihat dalam gambar 4.

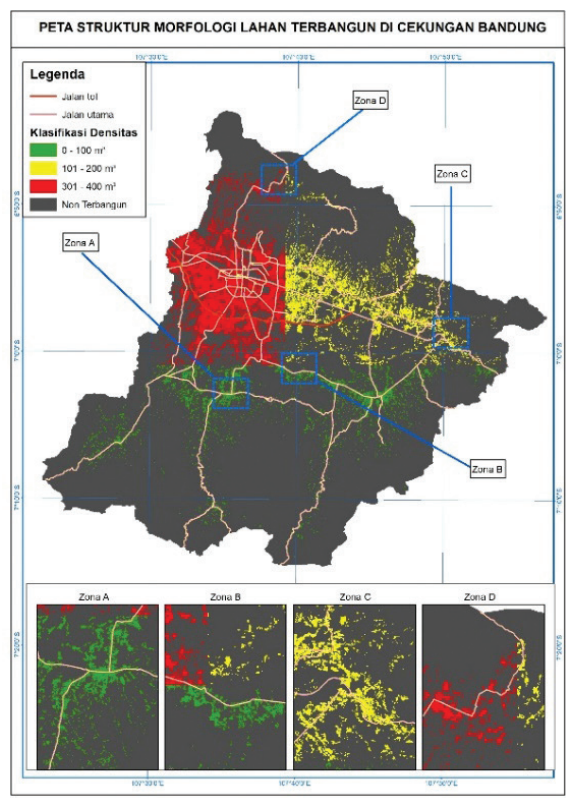

Gambar 4

Klasifikasi Morfologi Lahan Terbangun Tahun 2018

Sumber: Hasil Analisis tahun 2018 
Alam melakukan analisis pola perkembangan lahan terbangun menerapkan metode matematis dengan melihat nilai kepadatan lahan terbangun pada setiap sub wilayah mikro. Subwilayah mikro merupakan wilayah penelitian yang dibagi berdasarkan model Burgess dan model kuadran dengan radius 2 $\mathrm{Km}$ serta menghasilkan nilai kepadatan yang dapat menjadi dasar untuk mengklasifikasi pola perkembangan lahan terbangun di Cekungan Bandung periode 2009 - 2018.

Pola perkembangan wilayah lahan terbangun pada periode 2009 - 2018 dapat dilihat dari tingkat kepadatan lahan terbangun pada sub wilayah mikro yang telah terbagi menjadi 59 akan mencerminkan pola perkembangan lahan terbangun. Nilai kepadatan akan dilakukan pengkelasan untuk mengekstrak informasi pola perkembangan dengan interval data yang menerapkan perhitungan equal interval. Fenomena perkembangan lahan terbangun memiliki sifat perkembangan yang terdistribusi tidak merata ditinjau dari kepadatan lahan terbangun yang telah dilakukan pengkelasan pada setiap sudut dinilai pada mayoritas perkembangan yang terjadi di Cekungan Bandung Perhitungan dilakukan dengan menyelaraskan nilai kepadatan yang telah diubah menjadi kode yang dianalisis frekuensi dengan hasil interval 0,8 pada setiap radius. Jika nilai kepadatan memiliki perbedaan maka dikategorikan tidak radial dan ketika memiliki nilai kepadatan yang relatif sama maka dikatakan radial., lebih rincinya dapat dilihat dalam tabel 4.

Tabel 4

Kepadatan Lahan Terbangun Pada Sub Wilayah Mikro

\begin{tabular}{l|l|l|l|l}
\hline \multicolumn{1}{c|}{ JR } & \multicolumn{1}{|c|}{ ZN } & \multicolumn{1}{c|}{ KLT } & \multicolumn{1}{c}{ KD } & \multicolumn{1}{c}{ PL } \\
\hline 2 & TGR & 0.03 & 1 & Radial \\
\hline 2 & BL & 0.05 & 1 & Radial \\
\hline 2 & BD & 0.04 & 1 & Radial \\
\hline 2 & TL & 0.06 & 1 & Radial \\
\hline 4 & TGR & 0.05 & 1 & Non Radial \\
\hline 4 & BL & 0.09 & 2 & Non Radial \\
\hline 4 & BD & 0.01 & 1 & Non Radial \\
\hline 4 & TL & 0.03 & 1 & Non Radial \\
\hline 6 & TGR & 0.05 & 1 & Non Radial \\
\hline 6 & BL & 0.13 & 2 & Non Radial \\
\hline 6 & BD & 0.06 & 1 & Non Radial \\
\hline 6 & TL & 0.07 & 1 & Non Radial \\
\hline 8 & TGR & 0.04 & 1 & Non Radial \\
\hline 8 & BL & 0.09 & 1 & Non Radial \\
\hline 8 & BD & 0.05 & 1 & Non Radial \\
\hline 8 & TL & 0.14 & 2 & Non Radial \\
\hline 10 & TGR & 0.04 & 1 & Non Radial \\
\hline 10 & BL & 0.07 & 1 & Non Radial \\
\hline 10 & BD & 0.04 & 1 & Non Radial \\
\hline 10 & TL & 0.16 & 2 & Non Radial \\
\hline 12 & TGR & 0.04 & 1 & Non Radial \\
\hline 12 & BL & 0.05 & 1 & Non Radial \\
\hline & & & & \\
\hline 12
\end{tabular}

\begin{tabular}{l|l|l|l|l}
\hline \multicolumn{1}{|c|}{ JR } & \multicolumn{1}{|c|}{ ZN } & \multicolumn{1}{|c|}{ KLT } & \multicolumn{1}{|c}{ KD } & \multicolumn{1}{c}{ PL } \\
\hline 16 & TL & 0.09 & 2 & Non Radial \\
\hline 16 & BD & 0.03 & 1 & Non Radial \\
\hline 18 & BL & 0.04 & 1 & Radial \\
\hline 18 & TGR & 0.03 & 1 & Radial \\
\hline 18 & TL & 0.05 & 1 & Radial \\
\hline 20 & BD & 0.02 & 1 & Radial \\
\hline 20 & BL & 0.05 & 1 & Radial \\
\hline 20 & TL & 0.01 & 1 & Radial \\
\hline 20 & BD & 0.04 & 1 & Radial \\
\hline 22 & TGR & 0.01 & 1 & Radial \\
\hline 22 & BL & 0.08 & 1 & Radial \\
\hline 22 & BD & 0.02 & 1 & Radial \\
\hline 24 & TL & 0.05 & 1 & Radial \\
\hline 24 & BL & 0.01 & 1 & Non Radial \\
\hline 24 & BD & 0.02 & 1 & Non Radial \\
\hline 24 & TL & 0.04 & 1 & Non Radial \\
\hline 26 & TGR & 0.04 & 1 & Ron Radial \\
\hline 26 & BL & 0.05 & 1 & Radial \\
\hline 26 & BD & 0.02 & 1 & Radial \\
\hline 26 & TL & 0.02 & 1 & Radial \\
\hline & & & & \\
\hline
\end{tabular}


RAMADHAN PASCAWIJAYA, BOWO SUSILO, DAN PRIMA WIDAYANI POLA PERKEMBANGAN MORFOLOGI FISIK KOTA DI CEKUNGAN BANDUNG PERIODE ...

\begin{tabular}{l|l|l|l|l}
\hline \multicolumn{1}{c|}{ JR } & \multicolumn{1}{|c|}{ ZN } & KLT & KD & PL \\
\hline 12 & BD & 0.06 & 1 & Non Radial \\
\hline 12 & TL & 0.13 & 2 & Non Radial \\
\hline 14 & BL & 0.08 & 1 & Non Radial \\
\hline 14 & TGR & 0.04 & 1 & Non Radial \\
\hline 14 & TL & 0.10 & 2 & Non Radial \\
\hline 14 & BD & 0.07 & 1 & Non Radial \\
\hline 16 & BL & 0.06 & 1 & Non Radial \\
\hline 16 & TGR & 0.04 & 1 & Non Radial \\
\hline
\end{tabular}

\begin{tabular}{l|l|l|l|l}
\hline JR & ZN & KLT & \multicolumn{1}{|c|}{ KD } & PL \\
\hline 28 & TGR & 0.10 & 2 & Non Radial \\
\hline 28 & BL & 0.00 & 1 & Non Radial \\
\hline 28 & BD & 0.03 & 1 & Non Radial \\
\hline 28 & TL & 0.05 & 1 & Non Radial \\
\hline 30 & BD & 0.01 & 1 & Non Radial \\
\hline 30 & TL & 0.03 & 1 & Non Radial \\
\hline 34 & BD & 0.00 & 1 & Non Radial \\
\hline
\end{tabular}

Sumber : Hasil Analisis 2019

$\begin{array}{llll}\text { Ket } & : & \text { TGR } & =\text { Tenggara } \\ \mathrm{JR} & =\text { Jarak } & \mathrm{BD} & =\text { Barat Daya } \\ \mathrm{ZN} & =\text { Zona } & \mathrm{BL} & =\text { Barat Laut } \\ \mathrm{KD} & =\text { Kode } & \mathrm{TL} & =\text { Timur Laut } \\ \mathrm{PL} & =\text { Pola } & \mathrm{KLT} & =\text { Kepadatan lahan terbangun }\end{array}$

Tabel 4 menunjukkan klasifikasi pola perkembangan yang terjadi pada periode 20092018 adalah meloncat (Leapfrog) yang ditandai dengan distribusi perkembangan lahan terbangun dengan mayoritas perkembangan tidak merata, penentuan klasifikasi pola perkembangan dengan melihat bahwa adanya wilayah yang tidak berkembang secara merata pada wilayah radius $4-18 \mathrm{Km}, 24-26 \mathrm{Km}$, dan 28 - $36 \mathrm{Km}$ sebagai kategori mayoritas, sedangkan pada radius $0-2 \mathrm{Km}, 18-24 \mathrm{Km}$ dan 26 - $28 \mathrm{Km}$ bersifat merata (radial). Terjadi peloncatan lahan terbangun yang bersifat merata pada sub zona seperti: kelas Radial Non Radial - Radial Non Radial - Radial - Non Radial yang mencerminkan adanya peloncatan kelas radial pada radius tertentu, sehingga dapat disimpulkan perkembangan lahan terbangun bersifat meloncat (leapfrog) dengan interval kepadatan 0,8. Adapun perkembangan yang terjadi mengikuti pola jalan, sehingga perkembangan dapat dikategorikan pada perkembangan linear. Berikut presentasi peta pola perkembangan lahan terbangun dalam gambar 5.

Pola perkembangan pada periode 20092018 mempunyai pola leapfrog. Hal ini disebabkan oleh adanya perbedaan susunan kategori kepadatan lahan terbangun yang

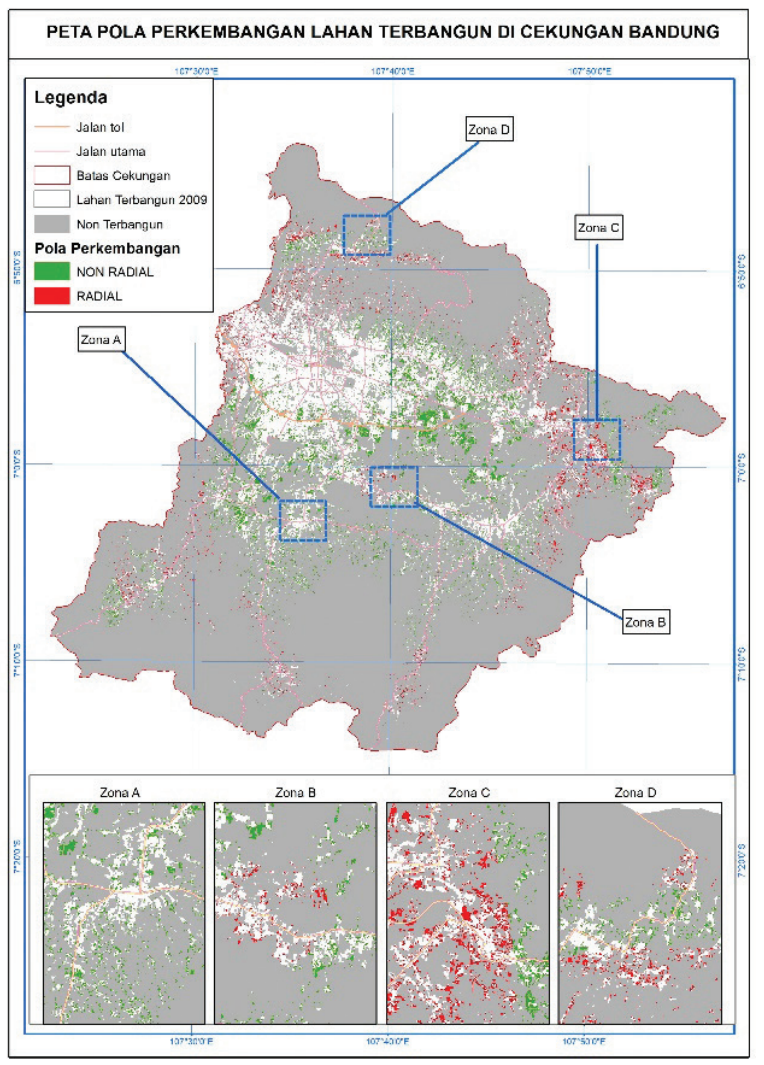

Gambar 5.

Pola Perkembangan Lahan Terbangun Periode 2009 - 2018

Sumber : Dokumentasi Penelitian tahun 2018 
terjadi di Cekungan Bandung. Hal tersebut disebabkan kota pinggiran yang mempunyai densitas lahan terbangun radial sehingga distribusi pembangunan lahan terbangun akan mengikuti lajur jalan namun mayoritas perkembangan lahan terbangun tumbuh pada titik pusat kota pinggiran ataupun persimpangan jalan utama sebagai dampak dari mobilitas yang terjadi antara pusat kota dengan pinggiran kota.

Adapun sifat perkembangan yang dianalisis secara visual dengan menggunakan metode lingkage, mayoritas perkembangan lahan terbangun mempunyai sifat yang linier (Memanjang) dilihat dari sudut persimpangan jalan. Perkembangan lahan terbangun yang bersifat linier terlihat pada gambar 5 dalam peta indeks yang menampilkan empat zona. Pada zona A terlihat perkembangan lahan terbangun mengikuti jalan, tetapi memiliki distribusi yang tidak merata, pada keadaan di lapangan perkembangan yang terjadi diakibatkan oleh adanya jalan lokal yang menjadi faktor pemicu perkembangan lahan terbangun pada kawasan tersebut, dengan kerapatan yang cenderung jarang, Zona B terlihat lebih padat perkembangannya dikarenakan kedekatan jarak pusat konsentris kota terhadap zona B yang dapat menjadi pemicu berkembangnya lahan terbangun, Zona $\mathrm{C}$ terlihat lebih padat dibandingkan zona lainnya serta pola memiliki bentuk yang memanjang dan agak teratur, hal ini dikarenakan pada Zona C masih termasuk pada Administrasi Kota Bandung, serta fasilitas yang dibutuhkan masyarakat cukup lengkap dan adanya pusat perguruan tinggi negeri menjadi pemicu perkembangan lahan terbangun yang berada pada zona C, sedangkan pada zona D memiliki bentuk yang teratur, hal ini dikarenakan pada zona tersebut merupakan kawasan wisata, sehingga perencanaan wilayah lebih banyak diterapkan. Pada penelitian ini terdapat temuan yang perlu dikemukakan terkait metode penelitian yaitu: luasan terkecil dalam satu unit mikro wilayah untuk menghitung kepadatan lahan terbangun yang dapat berdampak pada hasil penelitian.

\section{SIMPULAN}

Analisis pola perkembangan morfologi fisik kota di Cekungan Bandung, dapat disimpulkan bahwa pola perkembangan lahan terbangun di Cekungan Bandung pada periode 2009 - 2018 mempunyai struktur morfologi konsentris pada 2009 dan 2018 dengan sifat perkembangan yang non radial dan termasuk pada kategori leapfrog dan memiliki pola perkembangan linier mengikuti jalan. Dermawan, (2009), menyatakan bahwa pola perkembangan kota akan terbagi menjadi tiga kategori berdasarkan ciri fisiknya yaitu perkembangan radial, perkembangan linier dan perkembangan leapfrog. Bentuk morfologi fisik kota akan terlihat secara visual, bentuk morfologi fisik kota mempunyai variasi ekspresi dari bentuk kompak dan tidak kompak, diantaranya adalah: Bentuk bujur sangkar, bentuk empat persegi panjang, bentuk bulat, bentuk kipas, bentuk pita, bentuk gurita dan bentuk tidak berpola (Nelson, 1958 dalam Larasati, 2014). Secara keseluruhan Cekungan Bandung mempunyai morfologi lahan terbangun seperti Gurita dengan kepala gurita berada pada wilayah barat laut dengan mayoritas terletak pada administrasi Kota Cimahi dan Kota Bandung dan kakinya merupakan perkembangan yang terjadi mengikuti arah jalan utama yang terletak pada administrasi Kabupaten Bandung, Kabupaten Bandung Barat, dan Kabupaten Sumedang khususnya Kecamatan Jatinangor. Penelitian ini hanya mengkaji pola perkembangan yang dilihat pada tipe perkembangan horizontal (melebar), tidak mengkaji pada perkembangan tipe vertikal (tinggi bangunan), sehingga diperlukan kajian yang dalam untuk fenomena perkembangan kota.

\section{UCAPAN TERIMA KASIH}

Ucapan terima kasih disampaikan kepada bapak Dr. Bowo Susilo. M.T dan Ibu Dr. Prima Widayani. M.Sc. yang telah berkontribusi dalam penulisan penelitian yang dilakukan sehingga dapat menjadi salah satu ilmu yang dapat dijadikan sebagai bahan rujukan bagi peneliti lainnya. 


\section{DAFTAR PUSTAKA}

Adeel, M. (2010). Methodology for identifying urban growth potential using land use and population data : A case study of Islamabad Zone IV, International Society for Environmental Information Sciences, 2(5): 32-41. doi: 10.1016/j.proenv.2010.10.006.

Alqurashi, A. F. dan Kumar, L. (2013). Investigating the Use of Remote Sensing and GIS Techniques to Detect Land Use and Land Cover Change: A Review, Advances in Remote Sensing. 02(02): 193-204. doi: 10.4236/ars.2013.22022.

Ansar. Astin Lukum, Arifin dan Yudith J. Dengo. (2017). The influence of school culture on the performance of high school english teachers in Gorontalo Province, International Journal of Education and Research, 5(10): 35-48.

Brueckner, J. K. dan Helsley, R. W. (2011). Sprawl and blight, Journal of Urban Economics, 69(2): 205-213. doi: 10.1016/j.jue.2010.09.003.

BSN - Badan Standarisasi Nasional (2010). Klasifikasi penutup lahan, Badan Standarisasi Nasional, Jakarta: Badan Standarisasi Nasional..

Danoedoro, P. (2012). Pengantar Penginderaan Jauh. Edisi Pertama. Yogyakarta: Andi Offset.

Dermawan, E. (2009). Ruang publik dalam arsitektur kota. Edisi Pertama. Semarang: Badan Penerbit Universitas Diponegoro.

Fitriastin Larasati, N. (2014). “Tipologi ruang permukiman di kampung batik Semarang". Tesis, Semarang: Universitas Diponegoro.

Haack, B. N. dan Rafter, A. (2006). Urban growth analysis and modeling in the Kathmandu Valley, Nepal, Habitat International, 30(4):1056-1065. doi: 10.1016/j.habitatint.2005.12.001.
Hari, D. dan Rizki, B. (2016). Spatio temporal analysis trend of land use and land cover change against temperature based on remote sensing data in Malang City, Procedia - Social and Behavioral Sciences. 227(7): 232-238. doi: 10.1016/j.sbspro.2016.06.066.

Hartono dan Purwanto, T. H. (2017) Peran teknologi informasi geografi untuk mendukung ketangguhan bangsa: "Dari Foto Udara Hingga Augmented Reality Dalam Bingkai Informasi Geospasial". Seminar Nasional GEOTIK, Universitas Muhammadiyah Surakarta.

Horvat, Z. (2017). Using Landsat Satellite Imagery to Determine Land Use/Land Cover Changes in Međimurje County, Croatia, Hroatski geografski glasnik/Croatian Geographical Bulletin, 75(2): 5-28. doi: 10.21861/hgg.2013.75.02.01.

Jat, M. K., Choudhary, M. dan Saxena, A. (2017). The Egyptian Journal of Remote Sensing and Space Sciences Application of geo-spatial techniques and cellular automata for modelling urban growth of a heterogeneous urban fringe, The Egyptian Journal of Remote Sensing and Space Sciences, 20(2) : 223-241. doi: 10.1016/j. ejrs.2017.02.002.

Li, Z. dan Ai, T. (2004). Automated building generalization based on urban morphology and Gestalt theory Automated building generalization based on urban morphology and Gestalt theory, International Journal of Geographical Information Science. 18(5). doi: 10.1080/13658810410001702021.

Lillesand. (1997). Penginderaan jauh dan interpretasi citra (terjemahan bahasa Indonesia). Edisi Kedua, Yogyakarta: Universitas Gadja Mada: Universitas Gadja Mada.

Maktav, D. Erbek, F. S. dan Jürgens, C. (2013). Remote sensing of urban 
areas, International Journal of Remote Sensing. 26(4) 655-659. doi: $10.1080 / 01431160512331316469$.

Militino.A.F. Ugarte dan U. Pérez-Goya. (2018). An Introduction to the SpatioTemporal Analysis ofSatelliteRemote Sensing Data for Geostatisticians, Springer International Publishing AG part of Springer Nature, 13(6): 239-253. doi : 10.1007/978-3-319-78999-6_13.

Mundia, C. N. dan Aniya, M. (2017). Analysis of land use / cover changes and urban expansion of Nairobi city using remote sensing and GIS, International Journal of Remote Sensing, 26(13): 2831-2849 doi: 10.1080/01431160500117865.

Nelson. (1958). The Selection of RetailLocations. Edisi pertama. New York: Dodge Corporation.

Sanders. Paul. (2016). Applying urban morphology theory to design practice, Journal of Urban Design, 21(2):213-233. doi : 10.1080/13574809.2015.1133228.

Srinurak, N. Nobuo, M. Takayuki, F dan Wittaya, D. (2016). Analysis of urban morphology and accessibility character to provide evacuation route in historic area, Elsevier B.V, (216): 460-469. doi: 10.1016/j. sbspro.2015.12.061.

Sutanto. (1986). Penginderaan Jauh Jilid I. Edisi Pertama. Yogyakarta: UGM Press.

Tallo, A., Pratiwi, Y. dan Astutik, I. (2015). Identifikasi Pola Morfologi Kota (Studi Kasus: Kecamatan Klojen, Kota Malang), Jurnal Perencanaan Wilayah dan Kota. 25(3) : 213-227. doi: 10.5614/jpwk.2015.25.3.3.

USGS. (2013). Landsat-A Global LandImaging Mission. Diakses pada tanggal 12 Februari 2019. Dapat diakses di: https://pubs.usgs.gov/ fs/2012/3072/fs2012-3072.
USGS. (2019). Landsat 8 Data Users Handbook. Edisi keempat, South Dakota. Departement USGS.

Whitehand, J. W. R. (1987). The Changing Face of Cities: A Study of Development Cycles and Urban, The Town Planning Review. 61(2) :.209 doi: 10.3828/tpr.61.2.j63p2742133572m7.

Worku, T., Tripathi, M. S. K. dan Khare, D. (2016). Analyses of land use and land cover change dynamics using GIS and remote sensing during 1984 and 2015 in the Beressa Watershed Northern Central Highland of Ethiopia, Modeling Earth Systems and Environment. 2(4): 1-12. doi: 10.1007/ s40808-016-0233-4.

Xiuwan, C. (2010). Using remote sensing and GIS to analyse land cover change and its impacts on regional sustainable development, International Journal of Remote Sensing, 23(1), 107-124. doi: 10.1080/01431160010007051.

Yingui, C. A. O. Jing, W. Chun, Y. dan Wei, C. (2011). Spatial-temporal pattern and differences of land use changes in the Three Gorges Reservoir Area of China during 1975 - 2005 Spatialtemporal Pattern and Differences of Land Use Changes in the Three Gorges Reservoir Area of China during 1975-2005. Journal of Mountain Science. 4(8). doi: 10.1007/s11629011-2008-8.

Yuan, F. Kali E. Sawaya, Brian C. Loeffelholz, dan Marvin E. Baue. (2005). Land cover classification and change analysis of the Twin Cities (Minnesota) Metropolitan Area by multitemporal Landsat remote sensing. Elsevier, 98 (2-3) : 317-328. doi: 10.1016/j.rse.2005.08.006.

Yunus, H. S. (1994). Teori dan Model Struktur Keruangan Kota. Yogyakarta: Fakultas Geografi UGM.

Zanganeh. S, Sauri. D, Serra. P, Modugno. S, Seifolddini. P, dan Pourahmad. A.. 
(2011) 'Urban sprawl pattern and land-use change detection in Yazd, Iran', Habitat International. Elsevier Ltd, 35(4):521-528. doi: 10.1016/j. habitatint.2011.02.004.
Zhang, Y. dan Xu, B. (2015). Spatiotemporal analysis of land use / cover changes in Nanchang area, China, International Journal of Digital Earth. 4(8): 1-22. doi: 10.1080/17538947.2014.894145. 